\title{
Purification and characterization of D-2-haloacid dehalogenase from Pseudomonas putida strain AJ1/23
}

\author{
Judith M. SMith, ${ }^{*}$ Karen Harrison and John Colby \\ School of Biology, Sunderland Polytechnic, Sunderland SRI 3SD, UK
}

(Received 29 August 1989; revised 12 December 1989; accepted 18 January 1990)

\begin{abstract}
A D-2-haloacid dehalogenase was isolated and purified to homogeneity from Pseudomonas putida strain AJ1/23. The enzyme catalysed the stereospecific dehalogenation of the $D$-isomer of 2-chloropropionate. Using a new ionchromatograph assay, the enzyme was found to catalyse the dehalogenation of short-chain 2-halocarboxylic acids. Maximum enzyme activity occurred at $\mathrm{pH} 9.5$ and $50{ }^{\circ} \mathrm{C}$ and the enzyme was insensitive to most $-\mathrm{SH}$ reagents. The enzyme has an $M_{\mathrm{r}}$ of about 135000 and appears to be composed of four subunits of identical $M_{\mathrm{r}}$.
\end{abstract}

\section{Introduction}

Many xenobiotic compounds have been developed by man for pest control. Due to their recalcitrant nature they persist in the biosphere and may have damaging effects. Many xenobiotic compounds are halogenated; over $60 \%$ of herbicides contain at least one chlorine atom and dehalogenases may play a crucial role in their biodegradation (Slater, 1982).

2-Haloacid dehalogenases (EC 3.8.1.2) have been isolated from several strains of Pseudomonads (Goldman et al., 1968; Little \& Williams, 1971; Motosugi et al., 1982a, b; Slater et al., 1979; Weightman et al., 1982). They catalyse the reaction

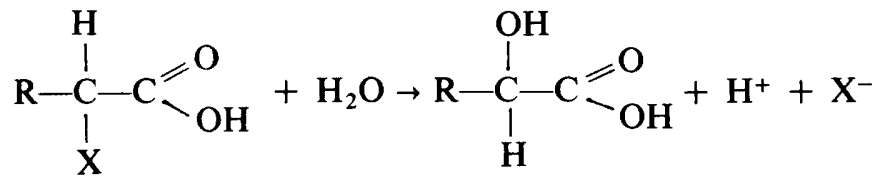

where $\mathrm{R}$ is a short-chain alkyl group or hydrogen and $\mathrm{X}$ is a halogen other than fluorine.

Until recently, it was thought that there were three types of 2-haloacid dehalogenases: those enzymes which act only on the L-isomer of 2-monochloropropionate, those which act on both the D- and the L-isomers with inversion of configuration, and those which act on both isomers but with the configuration maintained (Weightman et al., 1982). Recently, however, two 2-haloacid dehalogenases which act specifically on the D-isomer have been reported from separate sources. One enzyme was observed in Pseudomonas putida strain AJ1/23 (ICI

Abbreviation: 2-CPA, 2-chloropropionic acid.
Patent no. 179603, Smith et al., 1989); the other was isolated and partially purified from a strain of Rhizobium (Leigh et al., 1988).

In this paper, we describe the purification to homogeneity of the enzyme from $P$. putida $\mathrm{AJ} 1 / 23$ and report some of its structural and kinetic characteristics.

\section{Methods}

Organism and growth. Pseudomonas putida AJ1/23, isolated from a soil sample taken from an area exposed to chloropropionate, was provided by Dr S. C. Taylor, ICI Biological Products Business, Billingham, Cleveland, UK. It was grown in a 50 litre Bioengineering fermenter using 35 litres of growth medium containing $\left(\mathrm{g} \mathrm{l}^{-1}\right) \mathrm{K}_{2} \mathrm{HPO}_{4}$ (1.2), $\mathrm{KH}_{2} \mathrm{PO}_{4}(0.624),\left(\mathrm{NH}_{4}\right)_{2} \mathrm{SO}_{4}(1 \cdot 0), \mathrm{K}_{2} \mathrm{SO}_{4}(1 \cdot 0), \mathrm{CaCl}_{2} .2 \mathrm{H}_{2} \mathrm{O}$ $(0.05), \mathrm{MgSO}_{4} .7 \mathrm{H}_{2} \mathrm{O}(0 \cdot 2), \mathrm{NaCl}(0 \cdot 1)$, and $1 \mathrm{ml}$ of a trace elements solution containing $\left(\mathrm{g} \mathrm{l}^{-1}\right) \mathrm{CuSO}_{4} .5 \mathrm{H}_{2} \mathrm{O}(0 \cdot 18), \mathrm{MnSO}_{4} \cdot 7 \mathrm{H}_{2} \mathrm{O}(0 \cdot 88)$, $\mathrm{ZnSO}_{4} .7 \mathrm{H}_{2} \mathrm{O}(0.81)$, sterilized by autoclaving. After autoclaving, $10 \mathrm{mll}^{-1}$ of a filter-sterilized, acidified solution of $3.5 \mathrm{~g} \mathrm{FeSO}$. $7 \mathrm{H}_{2} \mathrm{Ol}^{-1}$ was added. Then $8 \mathrm{ml} \mathrm{l}^{-1}$ of a filter-sterilized solution of $2.5 \mathrm{M}$-racemic 2-chloropropionate (DL-2-CPA), which had been previously adjusted to $\mathrm{pH} 7.0$ with $\mathrm{NaOH}$, on ice, was added. Growth was estimated by measuring the culture optical density at $600 \mathrm{~nm}$ using a Pye-Unicam PU 8800 spectrophotometer. When the culture $\mathrm{OD}_{600}$ was about 1.0 , an additional $8 \mathrm{ml}^{-1} 2.5 \mathrm{M}$-DL-2-CPA solution was added. At an $\mathrm{OD}_{600}$ of about $2 \cdot 5$, the culture was harvested using a Alfa-Laval LAB 102B-05 solids-retaining separator. The cells were resuspended in $10 \mathrm{mM}$-Tris/ $\mathrm{H}_{3} \mathrm{PO}_{4}$ buffer, $\mathrm{pH} 7.5$ and centrifuged at $30000 \mathrm{~g}$ for $10 \mathrm{~min}$ at $4{ }^{\circ} \mathrm{C}$ in a MSE Hi-spin 21 centrifuge. The pelleted cells were stored at $-70^{\circ} \mathrm{C}$ in $25 \mathrm{~g}$ batches.

Preparation of crude cell extracts. Thawed cells were resuspended in $10 \mathrm{mM}$-Tris/ $/ \mathrm{H}_{3} \mathrm{PO}_{4}$ buffer, $\mathrm{pH} 7.5$ and sonicated with a MSE Uniprep 150 ultrasonic disintegrator using a $19 \mathrm{~mm}$ probe at amplitude $14 \mu \mathrm{m}$ for ten $30 \mathrm{~s}$ bursts separated by $30 \mathrm{~s}$ cooling periods. The sonicate was centrifuged at $38720 \mathrm{~g}$ and $4{ }^{\circ} \mathrm{C}$ for $30 \mathrm{~min}$ to remove suspended material. The supernatant, referred to as crude extract, was stored at $-70^{\circ} \mathrm{C}$ or used immediately. 
Protein estimation. Protein in samples was determined by the method of Bradford (1976) with Bio-Rad protein assay reagent using BSA as a standard.

Purification. All operations except HPLC were done at $4{ }^{\circ} \mathrm{C}$. All buffers contained 1 mM-DTT.

(i) DEAE-Sephacel chromatography. Crude extract was applied to a DEAE-Sephacel column $(15 \times 2.5 \mathrm{~cm})$ equilibrated with $10 \mathrm{mM}$ Tris $/ \mathrm{H}_{3} \mathrm{PO}_{4}$ buffer, $\mathrm{pH} 7.5$. The column was washed with $30 \mathrm{ml}$ of equilibration buffer and eluted at $0.5 \mathrm{ml} \mathrm{min}^{-1}$ with a $0.01-0.3 \mathrm{M}$ gradient of Tris $/ \mathrm{H}_{3} \mathrm{PO}_{4}$ buffer, $\mathrm{pH} 7.5 ; 2 \mathrm{ml}$ fractions were collected.

(ii) Ammonium sulphate precipitation. Active fractions were pooled and solid ammonium sulphate added to $50 \%$ saturation. The precipitate was collected by centrifugation at $14300 \mathrm{~g}$ for $10 \mathrm{~min}$ and resuspended in a small volume of $50 \mathrm{~mm}$-Tris $/ \mathrm{H}_{3} \mathrm{PO}_{4}$ buffer, $\mathrm{pH} 8.0$. The preparation was then dialysed against this buffer for at least $6 \mathrm{~h}$.

(iii) Gel-filtration chromatography. The dialysed enzyme was applied to an Ultrogel AcA-34 gel-filtration column $(90 \times 2.5 \mathrm{~cm})$ equilibrated with $50 \mathrm{~mm}$-Tris $/ \mathrm{H}_{3} \mathrm{PO}_{4}$ buffer, $\mathrm{pH} 8.0$ and eluted using this buffer at a flow rate of $0.3 \mathrm{ml} \mathrm{min}^{-1}$. Fractions $(5 \mathrm{ml})$ were collected; those containing dehalogenase were pooled and concentrated by precipitation with ammonium sulphate as above.

(iv) HPLC gel filtration. This was done at room temperature using a modular Gilson 302 HPLC system. Precipitated protein was resuspended in a small volume of buffer and dialysed overnight against $50 \mathrm{~mm}$-sodium phosphate buffer, $\mathrm{pH} 7 \cdot 2$. Samples $(200 \mu \mathrm{l})$ were applied to a TSK 3000SWG HPLC column, pre-equilibrated with sodium phosphate buffer and eluted at $0.5 \mathrm{ml} \mathrm{min}{ }^{-1}$. Fractions were collected at $1 \mathrm{~min}$ intervals.

Determination of purity. Samples of purified enzyme were run on $10 \%$ (w/v) polyacrylamide gels by the method of Laemmli (1970) and stained with methanolic Coomassie brilliant blue R250. Gels were dried onto filter paper using a Atto gel drier and scanned using a Beckman DU-70 spectrophotometer fitted with a film holder

Chromatofocusing. This was done on PBE exchanger. DEAESephacel eluate containing $35 \mathrm{mg}$ protein was loaded onto a chromatofocusing column $(1.5 \times 27 \mathrm{~cm})$ pre-equilibrated with $300 \mathrm{ml} 0.02 \mathrm{M}-$ imidazole/ $\mathrm{HCl}$ buffer, $\mathrm{pH} 7 \cdot 4$, containing $1 \mathrm{mM}-\mathrm{DTT}$. The column was eluted at a flow rate of $1 \mathrm{ml} \mathrm{min}^{-1}$ with a $\mathrm{pH} 7.5$ to $\mathrm{pH} 4.5$ gradient of polybuffer $74 ; 2 \mathrm{ml}$ fractions were collected. The fractions were measured for dehalogenase activity immediately after elution and their $\mathrm{pH}$ was measured on completion of the gradient.

Storage. Between purification stages, the enzyme was stored frozen at $-70^{\circ} \mathrm{C}$ or drop frozen in liquid nitrogen and then stored at $-70{ }^{\circ} \mathrm{C}$, both without significant loss of activity.

Measurement of dehalogenase activity. D-2-Haloacid dehalogenase activity was routinely determined by one of two methods.

(i) L-Lactate dehalogenase linked spectrophotometric assay. This assay was adapted from the lactate assay of Noll (1984). The principle of the assay is that the dehalogenase converts D-2-CPA to L-lactate; this in turn is oxidized to pyruvate by L-lactate dehydrogenase with concomitant reduction of NAD. The unfavourable equilibrium of this reaction is overcome by removal of pyruvate to form alanine by pyruvate :glutamate transaminase. Assay mixtures $(0.5 \mathrm{ml})$ contained $350 \mu \mathrm{l}$ distilled water, $15 \mu \mathrm{l} 50 \mathrm{~mm}-\mathrm{NAD}, 110 \mu \mathrm{l} 0.5 \mathrm{M}$-glutamate/ $\mathrm{NaOH}$ buffer, pH 10.0, $10 \mu \mathrm{l} 1 \mathrm{M}$-DL-2-CPA, $50 \mathrm{U}$ L-lactate dehydrogenase and $10 \mathrm{U}$ pyruvate : glutamate transaminase. After prewarming to $30^{\circ} \mathrm{C}$, the reaction was started by the addition of enzyme and the formation of NADH measured at $340 \mathrm{~nm}$ using a Pye-Unicam PU 8800 spectrophotometer.

(ii) Ion-chromatograph assay. This method is based on the measurement of $\mathrm{Cl}^{-}$in assay mixtures by HPLC. Ion chromatography was done using a Dionex QIC Analyser, fitted with a HPIC AS4A anion exchange column. Further details of this analysis have been described by Smith et al. (1989).

$M_{r}$ determination. The $M_{\mathrm{r}}$ of the native enzyme was determined by gel-filtration HPLC using a TSK G3000 SWG column. The column was calibrated using a Sigma MW-GF-200 kit, containing sweet potato $\beta$-amylase $\left(M_{\mathrm{r}} 200000\right)$, yeast alcohol dehydrogenase (150000), BSA (66000), carbonic anhydrase (29000) and cytochrome $c(12400)$. Each standard ( $2 \mathrm{mg})$ was loaded and eluted individually. The void volume $\left(V_{0}\right)$ of the column was $52.6 \mathrm{ml}$ (elution volume of Dextran Blue 2000 , $M_{\mathrm{r}} 2000000$ ). The relative retention of each protein, measured as elution volume/void volume $\left(V_{e} / V_{0}\right)$ was calculated and used to prepare a calibration curve.

Subunit $M_{\mathrm{r}}$ was determined by SDS-PAGE by the method of Laemmli (1970). Samples were run on a $8-20 \%(w / v)$ acrylamide gradient gel, calibrated using a Sigma MW-SDS-200 kit, containing the following proteins: myosin $\left(M_{\mathrm{r}}\right.$ 205000), $\beta$-galactosidase $(116000)$, phosphorylase $b(97400)$, BSA (66000), egg albumin (45000) and carbonic anhydrase (29000). Samples and standards containing $1 \%$ (w/v) SDS, $1 \%(\mathrm{v} / \mathrm{v}) 2$-mercaptoethanol and $20 \%(\mathrm{w} / \mathrm{v})$ sucrose were boiled for $2 \mathrm{~min}$. Bromophenol blue solution $(5 \mu \mathrm{l})$ serving as a front marker was added to all samples and markers. The gel was stained with methanolic Coomassie brilliant blue R250.

Materials. DL-2-Chloropropionate was obtained from Fluka. Other halogenated compounds (Table 2) were bought from Aldrich. Rabbit $\mathrm{L}(+)$-lactate dehydrogenase, Leuconostoc mesenteroides $\mathrm{D}(-)$-lactate dehydrogenase, porcine pyruvic transaminase, and DTT were obtained from Sigma. DEAE-Sephacel, Ultragel AcA-34, PBE exchanger and Polybuffer 74 were bought from Pharmacia.

\section{Results}

Purification of D-2-haloacid dehalogenase from P. putida AJI/23

P. putida AJ1/23 was grown as a fed-batch culture in a mineral medium containing DL-2-CPA as sole carbon and energy source. A maximum concentration of $20 \mathrm{mM}$ substrate was used, as higher concentrations were inhibitory to growth.

Of four different methods investigated in our laboratory for measuring dehalogenase activity, i.e. the Chloro-counter assay (Weightman et al., 1982), colorimetric assay (Bergmann \& Sanik, 1957), lactate dehydrogenase linked spectrophotometric assay (Noll, 1984) and ionchromatograph assay (Smith et al., 1989), the latter two methods were found to be the most useful. The lactate dehydrogenase linked assay was the quickest and was therefore useful in determining the distribution of dehalogenase in fractions collected after each purification step but could not be used for kinetic assays. The ion-chromatograph assay a sensitive assay developed in this laboratory was used to determine kinetic parameters of the enzyme and the specific activity of pooled samples (Table 1). 
Table 1. Purification of D-2-haloacid dehalogenase from P. putida AJ1/23

D-2-Haloacid dehalogenase was purified from crude extract by the procedure described in Methods. Enzyme activity was determined using the ion-chromatograph assay. One unit of dehalogenase activity is defined as the amount of enzyme catalysing the release of $1 \mu \mathrm{mol} \mathrm{Cl} \mathrm{Cl}^{-} \mathrm{min}^{-1}$.

\begin{tabular}{|c|c|c|c|c|c|c|}
\hline Fraction & $\begin{array}{l}\text { Activity } \\
\left(\mathrm{U} \mathrm{ml}^{-1}\right)\end{array}$ & $\begin{array}{l}\text { Total } \\
\text { activity } \\
\text { (U) }\end{array}$ & $\begin{array}{c}\text { Protein } \\
\text { concn } \\
\left(\mathrm{mg} \mathrm{ml}^{-1}\right)\end{array}$ & $\begin{array}{c}\text { Specific } \\
\text { activity } \\
{\left[\mathrm{U}(\mathrm{mg} \text { protein })^{-1}\right]}\end{array}$ & $\begin{array}{l}\text { Purification } \\
\quad \text { (-fold) }\end{array}$ & Yield \\
\hline Crude extract & $6 \cdot 0$ & 420 & $12 \cdot 0$ & 0.5 & 1.0 & 100 \\
\hline $\begin{array}{l}\text { DEAE-Sephacel } \\
\text { etate }\end{array}$ & $7 \cdot 5$ & 360 & $1 \cdot 3$ & $5 \cdot 8$ & $11 \cdot 6$ & 85 \\
\hline $\begin{array}{l}\text { Gel-filtration } \\
\text { eluate }\end{array}$ & $4: 1$ & 277 & $0 \cdot 15$ & $27 \cdot 3$ & $54 \cdot 6$ & 66 \\
\hline HPLC eluate & $5 \cdot 9$ & $118^{\circ}$ & $0 \cdot 39$ & $15 \cdot 3$ & $30 \cdot 6$ & 28 \\
\hline
\end{tabular}

The dehalogenase was purified by the four steps described in Methods. As shown in Table 1, the enzyme was purified 50 -fold by ion-exchange then gel-filtration chromatography. This preparation was $88 \%$ homogeneous as determined by gel-scanning of SDS-PAGE gels. Purification to $95 \%$ homogeneity was achieved by a further step using gel-filtration HPLC; however, this led to a significant decrease in specific activity. $\mathrm{pH}$ and temperature stability studies suggest these factors were not responsible.

On SDS-PAGE gradient gels, one clear band was observed giving an $M_{\mathrm{r}}$ value of $31800 \pm 500$, calculated from mobility relative to standards. Holoenzyme $M_{\mathrm{r}}$ was determined by gel-filtration HPLC. Comparison of retention time with standards gave an $M_{\mathrm{r}}$ of 134490 suggesting that the enzyme is a tetramer.

\section{Isoelectric point}

The isoelectric point of the enzyme was determined by chromatofocusing. Dehalogenase eluted in a single peak around $\mathrm{pH} \mathrm{5,} \mathrm{but} \mathrm{overnight} \mathrm{storage} \mathrm{under} \mathrm{these} \mathrm{condi-}$ tions led to complete loss of activity. Attempts to recover active enzyme by immediate dialysis of the enzyme on elution against $10 \mathrm{~mm}$-Tris $/ \mathrm{H}_{3} \mathrm{PO}_{4}$ buffer, $\mathrm{pH} 8 \cdot 0$, with or without prior concentration by ammonium sulphate precipitation, were unsuccessful.

\section{Kinetic parameters of dehalogenase determined using variations of the ion-chromatograph assay}

Effect of temperature. The highest measurable activity was recorded at $50{ }^{\circ} \mathrm{C}$; at higher temperatures the enzyme was rapidly inactivated. This correlates well with the results of experiments into the stability of enzyme at different temperatures (Fig. 1). Enzyme activity was very stable at 30 and $35^{\circ} \mathrm{C}$ (later experiments showed no loss of activity at $30^{\circ} \mathrm{C}$ and only $15 \%$ loss at $35^{\circ} \mathrm{C}$ after $3 \mathrm{~h}$ incubation). However, above $40^{\circ} \mathrm{C}$ loss of activity was readily observed, and at $56^{\circ} \mathrm{C}$ rapid inactivation of the enzyme was accompanied by visible protein precipitation. Replotting the data from Fig. 1 yielded an Arrhenius activation energy for the reaction of $53 \mathrm{~kJ} \mathrm{~mol}^{-1}$.

Effect of $p H$. The relationship between $\mathrm{pH}$ and enzyme activity is given in Fig. 2. Significant enzyme activits only occurred in alkali conditions which is consisteni with the nature of the reaction mechanism. Maximum activity was observed at $\mathrm{pH} \mathrm{9.5;} \mathrm{outside} \mathrm{the} \mathrm{range}$ pH $8 \cdot 0-10 \cdot 0$, less than $50 \%$ of this activity was seen. Below pH 5, there was rapid loss of enzyme activity. The enzyme was stable over the broad range $\mathrm{pH}$ 6-9, being less so in strongly alkali conditions.

Substrate specificity. The range of compounds dehalogenated by the enzyme was determined by modification of the ion-chromatograph assay (Table 2). In a separate experiment, the concentration of methanol added to aid dissolution of non-polar compounds was found not to affect enzyme activity. In control experiments, each substrate was observed under experimental conditions omitting enzyme. No significant spontaneous hydrolysis was observed with any of the compounds tested. Where some did occur (in all cases $<2 \%$ of substrate was hydrolysed over a $20 \mathrm{~min}$ incubation time) this rate was subtracted from observed enzyme reaction rates. The substrate range was fairly limited, there being a requirement for a free primary carboxyl group, the reactive halogen to be in the $\mathrm{C}-2$ position and an overall chain length not exceeding four carbons. Activity with iodoacetate could not be determined by this method due to the nature of the iodide peak. 


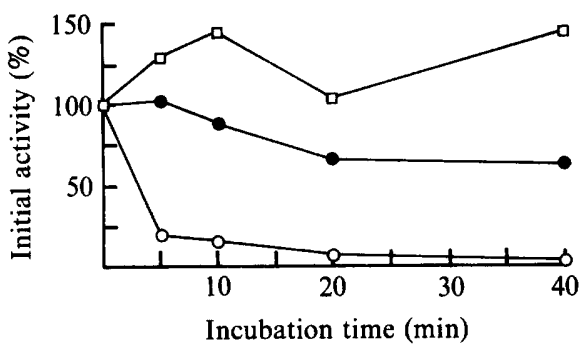

Fig. 1. Temperature stability of the enzyme. Enzyme samples $\left(0.5 \mathrm{mg} \mathrm{ml}^{-1}\right)$ were placed in microfuge tubes and incubated individually at $35(\square), 42(\bigcirc)$ and $56{ }^{\circ} \mathrm{C}(O)$. Samples of assay mixtures were taken at intervals and enzyme activity determined using the standard ion-chromatograph assay.

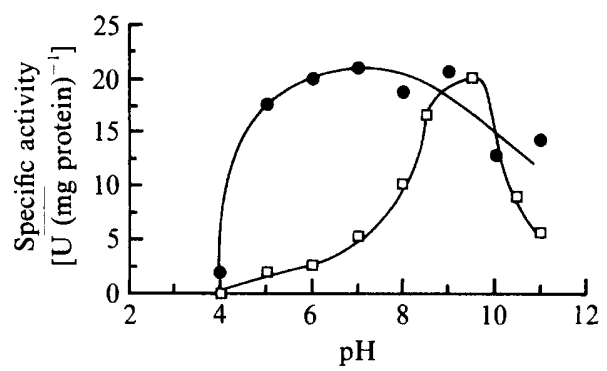

Fig. 2. pH profile of the enzyme. The effect of pH on enzyme activity ( $\square$ ) was determined in $200 \mathrm{mM}$ buffers using the ion-chromatograph assay. For determination of $\mathrm{pH}$ stability $(\odot)$, concentrated enzyme ( $2 \mathrm{mg}$ protein, $\mathrm{ml}^{-1}$ ) was incubated in $100 \mathrm{~mm}$ buffers for $20 \mathrm{~min}$. After diluting $1 / 10$ with $0.3 \mathrm{M}$-Tris $/ \mathrm{H}_{3} \mathrm{PO}_{4}$ buffer, $\mathrm{pH} 8.0,100 \mathrm{mM}$-DL-2-CPA was added. The residual activity was then determined using the ionchromatograph assay. The buffers used in both experiments were sodium acetate/acetate (pH 4 and 5), sodium phosphate (pH 6-8), Tris/ $\mathrm{H}_{3} \mathrm{PO}_{4}(\mathrm{pH} 8 \cdot 5-9 \cdot 5)$ and glycine/ $/ \mathrm{NaOH}(\mathrm{pH} \mathrm{10}-11)$.

\section{Table 2. Substrate specificity of the enzyme}

Halogenated compounds ( $50 \mathrm{mM} ; 5 \mathrm{~mm}$ if no activity was first observed with $50 \mathrm{mM}$ ) were substituted for DL-2-CPA in standard assay mixtures. The rat of release of $\mathrm{Cl}^{-}$or $\mathrm{Br}^{-}$from the compounds was measured using the ion-chromatograph assay and compared to that with DL-2-CPA. All compounds tested having chiral centres were racemic mixtures. Those not soluble in water were first dissolved in the minimum amount of methanol. No activity was observed with 2,3-dichloropropionate, 3-chloropropionate, 2-chloropropionamide, chloroacetaldehyde, bromoethanol, 2-chloroethanesulphonate, 2-bromodecanoate, 2-chloropropene, epichlorohydrin, epibromohydrin, chloroacetonitrile and fluoroacetate. Activity with DL-2-CPA (100\%) was $21.7 \mathrm{U}(\mathrm{mg}$ protein) $)^{-1}$.

\begin{tabular}{lc}
\hline \hline \multicolumn{1}{c}{ Substrate } & Relative activity (\%) \\
\hline DL-2-Chloropropionate & 100 \\
Bromoacetate & 405 \\
DL-2-Bromopropionate & $363 \cdot 5$ \\
Chloroacetate & 140 \\
2-Bromobutyrate & $13 \cdot 2$ \\
2,2-Dichloropropionate & $6 \cdot 7$ \\
2-Chlorobutyrate & $3 \cdot 3$ \\
\hline \hline
\end{tabular}

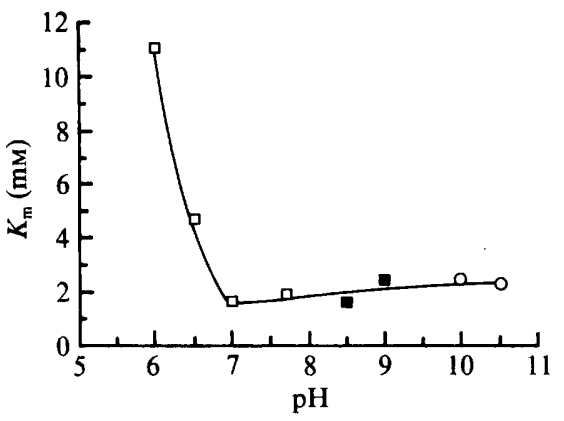

Fig. 3. Effect of pH on substrate $K_{\mathrm{m}}$. The relationship between $\mathrm{pH}$ and $K_{\mathrm{m}}$ for DL-2-CPA for $P$. putida D-2-haloacid dehalogenase was determined using the following buffers $(200 \mathrm{mM})$ : sodium phosphate $(\square)$; Tris/ $\mathrm{H}_{3} \mathrm{PO}_{4}(\square)$; glycine/ $\mathrm{NaOH}(O)$. Apparent $K_{\mathrm{m}}$ values were calculated from Lineweaver-Burk double reciprocal plots.

Stereospecificity. Enzyme stereospecificity was determined by two different methods. Firstly, the extent of dehalogenation of a known amount of substrate was measured in well-buffered assay mixtures using the ionchromatograph assay. Secondly, using the spectrophotometric assay, the activity of the enzyme with either Dor L-2-CPA was determined by linking with either rabbit L-lactate dehydrogenase or Leuconostoc mesenteroides D-lactate dehydrogenase. Following the reaction to completion, it was found that $46.7 \%$ of the substrate was dehalogenated. Activity was observed only with the combination of D-2-CPA and L-lactate dehydrogenase in assay mixtures. From this we assume that the enzyme is specific to the $\mathrm{D}$-isomer and that the reaction results in inversion of configuration.

$K_{m}$ for halo-acids. The relationship between $\mathrm{pH}$ and $K_{\mathrm{m}}$ for substrate was determined over the range $\mathrm{pH} 6 \cdot 0-10 \cdot 5$. Dehalogenase activity within the range 1.0-10 mM-DL-2CPA was determined using the ion-chromatograph assay. The results (Fig. 3 ) show that $K_{\mathrm{m}}$ broadly matches the pattern for specific activity of the enzyme with $\mathrm{pH}$ (Fig. 2). The $K_{\mathrm{m}}$ for D-2-CPA was assumed to be half that of DL-2-CPA, the substrate used in experiments.

Dehalogenase activity with certain other substrates was determined at $\mathrm{pH} 7.5$ using the ion-chromatograph assay. The $K_{\mathrm{m}}$ for chloroacetate was $27.5 \mathrm{mM}$ and for DL2-bromopropionate was $1.99 \mathrm{~mm}$.

Inhibitors. The effect of a variety of known enzyme inactivators on the activity of dehalogenase was determined using the ion-chromatograph assay (Table 3 ).

\section{Discussion}

2-Haloacid dehalogenases appear under various names in the literature: monobromoacetate dehalogenase (Tsang et al., 1988), haloacetate halidohydrolase (Kawa- 
Table 3. Effect of inhibitors on enzyme activity

Enzyme activity was measured using the ion-chromatograph assay after prior incubation in standard assay mixtures in the presence of inhibitor, but the absence of substrate, for $10 \mathrm{~min}$ at $30^{\circ} \mathrm{C}$. Activity was measured after the addition of substrate and is given as a percentage of a control assay with no added inhibitor. $100 \%$ activity was $21.7 \mathrm{U}$ (mg protein) $)^{-1}$ with DL-2-CPA as substrate.

\begin{tabular}{|c|c|}
\hline Inhibitor & Relative activity (\%) \\
\hline$N$-Ethylmaleimide $(10 \mathrm{~mm})$ & 46 \\
\hline $\mathrm{Fe}^{3+}(1 \mathrm{mM})$ & 100 \\
\hline $\mathrm{Fe}^{2+}(1 \mathrm{mM})$ & 98 \\
\hline $\mathrm{Cu}^{2+}(10 \mathrm{mM})$ & 27 \\
\hline $\mathrm{KCN}(1 \mathrm{mM})$ & 100 \\
\hline $\mathrm{HgSO}_{4}(1 \mathrm{~mm})$ & 100 \\
\hline$p$-Chloromercuribenzoate $(0.1 \mathrm{mM})$ & 111 \\
\hline $\mathrm{HgCl}_{2}(1 \mathrm{~mm})$ & 114 \\
\hline Dithionitrobenzoate $(10 \mathrm{~mm})$ & 63 \\
\hline Iodoacetate $(10 \mathrm{mM})$ & 64 \\
\hline$(1 \mathrm{~mm})$ & 100 \\
\hline
\end{tabular}

saki et al., $1981 a, b$ ), halidohydrolase (Little \& Williams, 1971), DL-2-haloacid dehalogenase (Motosugi et al., 1982a) and 2-halo acid dehalogenase (Motosugi et al., $1982 b$ ). All have specificity for substrate of short carbonchain length, a free primary carboxyl group and the reactive carbon in the $\mathrm{C}-2$ position. However, their relative activities towards individual compounds are different. In this respect, D-2-haloacid dehalogenase from $P$. putida AJ1/23 most resembles the enzymes described by Motosugi et al. (1982a) and by Little \& Williams (1971).

The $M_{\mathrm{r}}$ of $P$. putida AJ1/23 D-2-haloacid dehalogenase was determined to be 134000 , composed of subunits of $M_{\mathrm{r}} 31800$. This value is between 2- and 4-fold higher than that described for the above enzymes.

$P$. putida AJ1/23 D-2-haloacid dehalogenase displays a $\mathrm{pH}$ optimum of 9.5 , identical to that of most 2-haloacid dehalogenases; it possesses a similar broad stability range, $\mathrm{pH} 6 \cdot 0-10 \cdot 0$. The temperature optimum of $50^{\circ} \mathrm{C}$ is also close to other quoted values.

Isoelectric points have been quoted only for haloacetate dehalogenases (Kawasaki et al., 1981 $a, b$ ) which, at 5.4 and 5.2 respectively, are very similar to the value 5.0 found for the $P$. putida AJ1/23 D-2-haloacid dehalogenase.

From published data, it appears that susceptibility to -SH reagents varies with the different groups of dehalogenases. (i) Those enzymes which dehalogenate fluoroacetate are very susceptible (Kawasaki et al., 1981a). (ii) Enzymes which dehalogenate DL-2-CPA with inversion of configuration, are not susceptible, whilst (iii) those that retain configuration are sensitive (Motosugi et al., 1982a; Weightman et al., 1982). (iv) L-2CPA dehalogenase susceptibility appears to depend on the source of the enzyme (Little \& Williams, 1971; Motosugi et al., 1982b). D-2-Haloacid dehalogenase from $P$. putida $\mathrm{AJ} 1 / 23$ is resistant to inhibition by $-\mathrm{SH}$ reagents, and thus resembles the second group. DTT, which retains $-\mathrm{SH}$ groups in the reduced condition is required to maintain long-term enzyme stability. The enzyme may be partially purified in its absence, but with reduced activity. Activity can then be enhanced by adding DTT. Insensitivity of the enzyme to mercurials suggest that the $-\mathrm{SH}$ groups are not at the active site.

A mechanism for dehalogenation of 2-CPA resulting in inversion of configuration was proposed by Weightman et al. (1982). The active site configuration postulated has a positively charged pocket to bind the carboxylate group which is in close proximity to a basic group which will promote nucleophilic attack. This proposal is consistent with the substrate and $\mathrm{pH}$ range of $P$. putida AJ1/23 D-2-haloacid dehalogenase. The $\mathrm{pH} /$ activity profile of the enzyme (Fig. 2) suggests that binding of 2-CPA occurs even at high $\mathrm{pH}$ values. A fall in activity is seen above $\mathrm{pH} 10 \cdot 0$; thus the positively charged pocket binding the carboxylate group must be strongly basic. Lysine and arginine, with $\mathrm{p} K_{\mathrm{a}}$ values of $\sim 10$ and $>12.0$ respectively (Metzler, 1977) may be present at this site. 2-CPA is a strong acid $\left(\mathrm{p} K_{\mathrm{a}} 2.83\right.$; Weast, 1986) and thus is in the dissociated form throughout the $\mathrm{pH}$ range of enzyme activity. The enzyme shows a rapid increase in activity above $\mathrm{pH} 7 \cdot 0$; also, as indicated in Fig. 3, $K_{\mathrm{m}}$ for substrate over the $\mathrm{pH}$ range $6-10$ is fairly constant. Below $\mathrm{pH} 7 \cdot 0, K_{\mathrm{m}}$ and activity both fall off rapidly. A histidine residue ( $K_{\mathrm{a}} 6 \cdot 4-7 \cdot 0 ;$ Metzler, 1977) may act as the basic group which promotes nucleophilic attack, as in the proposed mechanism.

In a series of experiments, Little \& Williams (1971) found that 2,4,6-trinitrobenzene sulphonate inhibited halidohydrolase activity only marginally and both phenylmethanesulphonyl fluoride and $\mathrm{N}$-acetylimidazole had no effect. They concluded that it was unlikely that free amino, seryl or tyrosyl residues were involved in the enzyme reaction. Susceptibility to photo-oxidation and the results of kinetic experiments were found to be consistent with the presence of an active histidine residue. Similar experiments could be done on the $P$. putida D-2-haloacid dehalogenase to help elucidate active-site structure.

We acknowledge financial assistance from ICI Biological Products Business, and Dr S. C. Taylor and Dr J. M. Liddell for their help and provision of $P$. putida strain AJ1/23. K. H. thanks SERC for a Quota Studentship.

\section{References}

BergmanN, J. G. \& SANIK, J. (1957). Determination of trace amounts of chloride in naphtha. Analytical Chemistry 29, 241-243. 
Bradford, M. M. (1976). A rapid and sensitive method for the quantitation of microgram quantities of protein utilizing the principle of protein-dye binding. Analytical Biochemistry 72, 248-254.

Goldman, P., Milne, G. W. A. \& Keister, D. B. (1968). Carbonhalogen bond cleavage. III. Studies on bacterial halidohydrolases. Journal of Biological Chemistry 243, 428-434.

Kawasaki, H., Miyoshi, K. \& Tonomura, K. (1981a). Purification, crystallisation and properties of haloacetate halidohydrolase from Pseudomonas species. Agricultural and Biological Chemistry 45, 543-544.

Kawasaki, H., Tone, N. \& Tonomura, K. (1981 $b)$. Purification and properties of haloacetate halidohydrolase specified by plasmid from Moraxella sp. strain B. Agricultural and Biological Chemistry 45, 35-42.

LAEMMLI, U. K. (1970). Cleavage of structural proteins during the assembly of the head of bacteriophage T4. Nature, London 227, 680-685.

Leigh, J. A. Skinner, A. J. \& Cooper, R. A. (1988). Partial purification, stereospecificity and stoichiometry of three dehalogenases from Rhizobium species. FEMS Microbiology Letters 49, 353-356.

LITTLE, M. \& Williams, P. A. (1971). A bacterial halidohydrolase. Its purification, some properties and its modification by specific amino acid reagents. European Journal of Biochemistry 21, 99-109.

METZLER, D. E. (1977). Biochemistry. The Chemical Reactions of Living Cells, p. 59. New York: Academic Press.

Motosugi, K., Esaki, N. \& Soda, K. (1982a). Purification and properties of a new enzyme, DL-2-haloacid dehalogenase, from Pseudomonas sp. Journal of Bacteriology 150, 522-527.
Motosugi, K., Esakı, N. \& SodA, K. (1982b). Purification and properties of 2-halo acid dehalogenase from Pseudomonas putida. Agricultural and Biological Chemsitry 46, 837-838.

NolL, F. (1984). In Methods of Enzymatic Analysis, vol. 6, Metabolites, 1, Carbohydrates, pp. 582-588. Edited by H. U. Bergmeyer. Weinheim, FRG: Verlag Chemie.

Slater, J. H. (1982). New microbes to tackle toxic compounds. South African Journal of Science 78, 101-104.

Slater, J. H., Lovatt, D., Weightman, A. J., Senior, E. \& Bull, A. T. (1979). The growth of Pseudomonas putida on chlorinated aliphatic acids and its dehalogenase activity. Journal of General Microbiology 114, 125-136.

Smith, J. M., Harrison, K., Colby, J. \& Taylor, S. C. (1989). Determination of $\mathrm{D}$-2-halopropionate dehalogenase activity from Pseudomonas putida strain AJ1/23 by ion chromatography. FEMS Microbiology Letters 57, 71-74.

Tsang, J. S. H., Sallis, P. J., Bull, A. T. \& Hardman, D. J. (1988). A monobromoacetate dehalogenase from Pseudomonas cepacia MBA4. Archives of Microbiology 150, 441-446.

Weast, R. C. (editor) (1986). CRC Handbook of Chemistry and Physics, 67th edn. Boca Raton, Florida: CRC Press.

Weightman, A. J., Slater, J. H. \& Bull, A. T. (1979). The partial purification of two dehalogenases from Pseudomonas putida PP3. FEMS Microbiology Letters 6, 231-234.

Weightman, A. J., Weightman, A. L. \& Slater, J. H. (1982). Stereospecificity of 2-monochloropropionate dehalogenation by the two dehalogenases of Pseudomonas putida PP3: evidence for two different dehalogenation mechanisms. Journal of General Microbiology 128, 1755-1762. 